doi: 10.17492/pragati.v3i2.7745

\title{
Structural Changes in Direction of India's Exports under New Trade Policy
}

\author{
Manoj Kumar Sinha*
}

\begin{abstract}
The main objective of this paper is to analyse the structural changes in direction of India's exports under the New Trade Policy since 1991. The period of study is 1987-88 to 2014-15. The paper uses the dominance pattern, ranking technique, mobility and turnover, concentration ratio and growth rate technique as research methodology for analysis. The results show that USA, UAE, Hong Kong, UK and Germany accounted for more than 62 percent of exports from India at the world level. UAE and Hong Kong are Asian Countries in top five and accounted for around 24 percent of India's export. World concentration ratio of exports from India is negative, declining and low. In case of developing countries, UAE has emerged as the most important trading partner followed by Hong Kong, Singapore, Saudi Arabia and Bangladesh and accounted for more than 64 percent of India's export to developing countries. Bangladesh is the only SAARC country in top five developing countries, while China and Russia of BRICS countries are in top list of India's exports. India's direction of foreign trade has exhibited a structural shift during the last two decades. Trade volume and trade share of emerging and developing economies has increased while the share of conventional trading partners (developed countries) has showed a declining trend.
\end{abstract}

Key Words: New Trade Policy, Export Direction, Dominance, Concentration, Mobility and Turnover.

\subsection{Introduction}

The process of globalisation got momentum in India with the opening up of economy in 1991. This facilitated the process of economic integration and expansion of volume of international trade. India's opening up of international trade and its expansion of international trade was a crucial aspect of the new approach to economic policy and an integral part of the process of economic reforms.

*Assistant Professor, PGDAV College, University of Delhi. (email: mksinhadu@gmail.com) 
In 1991, the government introduced some changes in its policy on trade, foreign investment, tariffs and taxes under the name of 'New Economic Reforms'. The economic reforms process introduced since 1991 with focus on liberalisation, openness, transparency and globalisation has enabled increased integration of the Indian economy with the rest of world. The growth rate of India's trade is increasingly dependent on exogenous factors such as world trade growth (especially those of the trading partners), international price changes and development in the competitor countries. Cross currency exchange rates as well as dollar rupee exchange rate movements also get reflected in the performance of India's trade. Indian exports have come a long way from the time of independence in terms of value. The total value of India's merchandise exports increased from US $\$ 1.3$ billion in 1950-51 to US $\$ 63.8$ billion in 2003-04 - a compound rate of 7.6 per cent (Malik, 2005). Indian economy and foreign trade has shown progress post liberalisation. In contrast to the pre-reform period (1950-90), the actual growth of exports in the post-reform period has been above the potential offered by the growth of world demand. The gap between the actual and potential is mainly explained by an improvement in the overall competitiveness of India's exports (Virmani, 2003; Veeramani, 2007).

The direction and composition of India's foreign trade has undergone substantial changes, particularly, after the liberalisation and globalisation (Mathor and Sagar, 2015). Direction of foreign trade means the countries to which India exports its goods and the countries from which it imports. Thus direction consists of destination of exports and sources of our imports. Prior to our Independence when India was under British rule, much of our trade was done with Britain. Therefore, UK used to hold the first position in India's foreign trade. However, after Independence, new trade relationships were established. Now USA has emerged as the most important trading partner followed by Germany, Japan and UK. India is also making efforts to increase the exports to other countries also the direction of India's exports and imports. India's direction of foreign trade has exhibited a structural shift during the last decade. The main purpose of the paper is to analyze the structural changes in India's direction of export during new trade policy since 1991.

\subsection{Literature Review}

Mitra (2007) observed two important features in India's trade patterns: one, the share of developed countries i.e. EU, USA and Japan declined in both exports and imports and while share of developing countries i.e. Asia, Africa and Latin America increased; and second, there has been an increase in the share of trade to China and the Middle East 
such as the UAE and Saudi Arabia. The trends also indicate that the Asian region including China has emerged over the years as India's most important trading partner in place of the EU. The important destinations for exports from India are USA, EU, UAE, China and Africa. Bhat (2011) found that the most striking feature is the growing importance of Asia as India's export destination. Asian share in total exports has increased by substantial proportion and it is nearly 55 per cent in 2010-11. This is due to India's 'Look East Policy' and sustained effort to develop strong relations with China and the ASEAN. At the same time, it is also attributable to the declining share of the EU and the US. Concerted effort has been made to develop trade relation with Africa and Latin America. Mishra, Jena and Shil (2011) observed that India's exports have recorded a remarkable change during the last two decades. The most remarkable change in the direction of exports is with regard to Eastern Europe whose share in India's export was 22.1 percent in 1980-81 declined to 2.0 percent in 2006-07. This is due to the disintegration of USSR. The share of OPEC in India's export maintained a steady rising trend i.e., from 11.1 percent in 1980-81 to 16.3 percent in 2006-07.

Taneja (2013) stated that India's major trading partners are also changing. The share of developed countries (EU and North America) which was approximately 58 percent in India's total exports till the end of first decade of reforms fell to percent and 29 percent in 2007-08 and 2011-12. On the other hand, the share of developing countries (Asia, Africa and Latin American) which used to account $29 \%$ share in total exports by 1999 2000 reported $40 \%$ share in 2011-12. This structural shift in India's direction of exports is mainly considered to be the result of market diversification strategy which was initiated with the launch of Focus LAC and Focus Africa in the late 1990s and further extended through Focus Market and Market Linked Focus Product Scheme in 2006. This market diversification strategy has provided a wider scope to Indian exporters to venture into Africa, Latin America and other less explored regions.

The existing literature considered direction of India's exports as a part of the study of composition and direction of foreign trade. However, there is relatively less literature that focuses on detailed and comprehensive ways to study the structural changes in direction of India's export of goods and services. This literature gap is the main motivation for the study of this paper. There has been a considerable change in direction of export of goods and services since integration of Indian economy with the world under New Trade Policy 1991. This paper focuses on the changes in India's export direction of goods and services under shift of foreign trade policy from 'importsubstitution' to 'export-promotion' strategy. This paper contributes to the existing literature through comprehensive and detailed dynamics of direction of goods and services of India's export during post reforms period. 
62 | PRAGATI: Journal of Indian Economy, Volume 3, Issue 2

\subsection{Data and Research Methodology}

\subsection{Data sources}

The study uses secondary data published by Reserve Bank of India (RBI) (www.rbi.org.in) on direction of India's export of goods and services. The period of study is $1987-88$ to $2014-15$.

\subsection{Dominance patterns}

Dynamic changes in the pattern of export of commodities would result in changing ranks of different commodities exported from India. This represents a state of competition amongst exported commodities. It is normally not possible for any single commodity to dominate to be exported for whole period 1987 to 2013. Even if a commodity is not at top in one or more years it should be possible to capture the dominating exported commodity. It is interesting to know whether there is any dominant commodity or a constant flux in the ranking of different commodities. Dominance can be studied in three ways:

a) The rankings patterns at three points of time, which is a discrete measure of dominance.

b) Index of Rank Dominance (IRD) which is a relative dominance measure by ranks, (Murthy, 2011). This is measure of continuous dominance.

c) Bodenhorn's measure of competition.

The index of rank dominance (IRD) is an innovative measure which tells us a coefficient that expresses the degree of dominance of an ordinal measure such as rank. IRD has further refined as a relative- Relative Index of Rank Dominance (RIRD), which measures dominance in a relative sense. This gives the proportionate weight of the rank dominance index.

\section{Index of rank dominance}

The top ten commodities which have the dominant position (i.e. highest rank) for the longest period is estimated with the help of index of rank dominance (Murthy, 2011).

where

$$
I_{R D}=\frac{\sum_{i=1987}^{2013}(\text { Rank Score })_{i}}{\text { Maximum Rank Score X No.of Years }}
$$

$\boldsymbol{I}_{\boldsymbol{R} \boldsymbol{D}}=$ is the index of Rank Dominance.

Rank Score $=10,9,8 \ldots$ (in decreasing order of rank).

There are four properties of this new index:

a) The value of $\boldsymbol{I}_{\boldsymbol{R} \boldsymbol{D}}$ lies between 0 and 1, that is, $0<I_{R D} \leq 1$ 
$\boldsymbol{I}_{\boldsymbol{R} \boldsymbol{D}}$ measures in relative terms the position of the most dominant commodity over period from 1987 to 2013 for exporting commodity. The value of $\boldsymbol{I}_{\boldsymbol{R} \boldsymbol{D}}$ lies between zero and one but never become zero because in this index, commodities included must be at least one time be placed in the top ten positions over the period 1987 to 2013. The maximum value of $\boldsymbol{I}_{\boldsymbol{R} \boldsymbol{D}}$ shall be one provided a commodity has been at top position in all years from 1987 to 2013 for exporting commodity from India.

b) IRD is a measure of continuous dominance.

c) RIRD enables measuring the relative continuous dominance.

d) IRD is a measure that applies to panel data. That is it measures the dominance and amongst ' $\mathrm{N}$ ' countries over a time periods of ' $\mathrm{T}$ ' years.

\section{Mobility and Turnover}

This is the sum of rank changes among the top exporting commodities from India. Mobility means changes in rank position within leading commodities. The measure of turnover as the number of commodities below the leading commodities exported from India replace the commodities belonging to the leading commodities exported. In mobility and turnover the changes in rank of current year are with respect to previous year. These measure the competition among commodities exported from India. This mobility and turnover are based on Bodenhorn, et al. (1990). Measure of mobility and turnover over the periods 1987 to 2013 are calculated and the significance of their difference are tested. This is done with a view to understand whether dominance pattern of commodities exported from India has changed, Murthy and Deb (2008).

\subsection{Herfindahl-Hirschman Index of Concentration}

Herfindahl-Hirschman Index (HHI) is a commonly accepted measure of market concentration. It is calculated by squaring the market share of each commodity exported from India and then summing the resulting number (Murthy and Deb, 2008). The HHI is expressed as:

$$
H H I=\sum_{i=1}^{N} S_{i}^{2}
$$

where ' $\mathrm{Si}$ ' is the market share of exported commodity ' $\mathrm{i}$ ' in the market and ' $\mathrm{N}$ ' is the number of commodities. This index ranges from $1 / \mathrm{N}$ to one, where ' $\mathrm{N}$ ' is the number of commodities.

HHI index below 0.01 indicates a highly competitive market.

$\mathrm{HHI}$ index below 0.1 indicates that market is not concentrated.

$\mathrm{HHI}$ index between 0.1 to 0.18 indicates low concentration of market.

HHI index above 0.18 to 0.30 indicates moderate concentration of market.

$\mathrm{HHI}$ index above 0.30 indicates high concentration of market. 


\subsection{Empirical Analysis}

\subsection{India's exports to the world}

India's direction of foreign trade has exhibited a structural shift during the last decade. Trade volume and trade share of emerging and developing economies has increased while the share of conventional trading partners has shown a declining trend (PHD Chamber, 2014). Dominance pattern explains the dynamics of change in direction of India's export during the new foreign trade policy since 1991. USA is an important trading partner of India and at top position. India's export to USA has significantly increased in terms of volume and value. India is exporting more than 17 percent of total exports to USA. The top five countries, viz., USA, UAE, Hong Kong, UK and Germany, account for more than 62 percent of India's exports. UAE and Hong Kong are Asian countries in top five and account for around 24 percent of India's export. The top ten countries account for more than 90 percent of India's export. Out of these top ten countries, five countries are Asian countries and account for more than 40 percent of India's total exports. This result indicates major shift of India's trading strategy towards Asia. However, India's export dominance pattern is top-heavy.

Table 1: Rank Dominance of World in India's Exports during 1987-88:2013-14

\begin{tabular}{|l|c|c|c|c|}
\hline Country & Presence & Score & IRD & RIRD \\
\hline U.S.A & 27 & 264 & 0.978 & 0.178 \\
\hline U.A.E. & 27 & 188 & 0.696 & 0.127 \\
\hline Hong Kong & 27 & 166 & 0.615 & 0.112 \\
\hline U.K. & 27 & 166 & 0.615 & 0.112 \\
\hline Germany & 27 & 147 & 0.544 & 0.099 \\
\hline Japan & 21 & 120 & 0.444 & 0.081 \\
\hline China & 12 & 90 & 0.333 & 0.061 \\
\hline Belgium & 24 & 84 & 0.311 & 0.057 \\
\hline Singapore & 17 & 83 & 0.307 & 0.056 \\
\hline Russia & 11 & 57 & 0.211 & 0.038 \\
\hline Italy & 21 & 51 & 0.189 & 0.034 \\
\hline Netherlands & 8 & 31 & 0.115 & 0.021 \\
\hline Saudi Arabia & 4 & 13 & 0.048 & 0.009 \\
\hline France & 9 & 12 & 0.044 & 0.008 \\
\hline Bangladesh & 6 & 11 & 0.041 & 0.007 \\
\hline Indonesia & 2 & 2 & 0.007 & 0.001 \\
\hline & & Total & 5.5 & 1 \\
\hline
\end{tabular}


Among BRICS economies, India export only to China and Russia which accounts for around 10 percent of exports. India's export to SAARC countries is less than one percent (Table 1). India needs to diversify trading direction of export more intensively and extensively. This will lead to increase in India's exports and will also help to reduce dependence on developed countries such as USA, UK. This will also absorb global shock and recession such as global financial crisis in 2008.

Table 2 shows the mobility and turnover of India's exports, which essentially measures the structural changes in direction of India's exports.

Table 2: Mobility and Turnover of India's Exports to the World

\begin{tabular}{|c|c|}
\hline Year & Mobility \&Turnover \\
\hline 1988-89 & 4 \\
\hline $1989-90$ & 2 \\
\hline $1990-91$ & 2 \\
\hline $1991-92$ & 10 \\
\hline 1992-93 & 13 \\
\hline 1993-94 & 6 \\
\hline $1994-95$ & 4 \\
\hline $1995-96$ & 7 \\
\hline 1996-97 & 8 \\
\hline $1997-98$ & 9 \\
\hline 1998-99 & 13 \\
\hline 1999-00 & 4 \\
\hline $2000-01$ & 5 \\
\hline 2001-02 & 6 \\
\hline $2002-03$ & 10 \\
\hline 2003-04 & 6 \\
\hline $2004-05$ & 12 \\
\hline $2005-06$ & 2 \\
\hline 2006-07 & 2 \\
\hline $2007-08$ & 7 \\
\hline 2008-09 & 10 \\
\hline $2009-10$ & 10 \\
\hline $2010-11$ & 7 \\
\hline 2011-12 & 2 \\
\hline $2012-13$ & 10 \\
\hline 2013-14 & 10 \\
\hline Average & 7.0 \\
\hline
\end{tabular}


Table 2 shows the change in ranks of India's export to the countries in a particular year with respect to the corresponding previous year. If the magnitude of mobility and turnover is low, then there are a few changes in directions of India's exports and vice-versa. The maximum mobility and turnover is 13 in years 1992-93 and 1998-99 while minimum is 2 in years 1989-90, 1990-91, 2005-06, 2006-07 and 2011-12. This indicates that the fluctuation in the direction of India exports is low but has occurred repeatedly. Overall mobility and turnover is 7 per annum on an average basis. This may be because India has taken a number of initiatives to add new trading partners and other measures of export promotion since 1991. The line graph (Figure 1) clearly indicates that there is no stable pattern of change in direction of export.

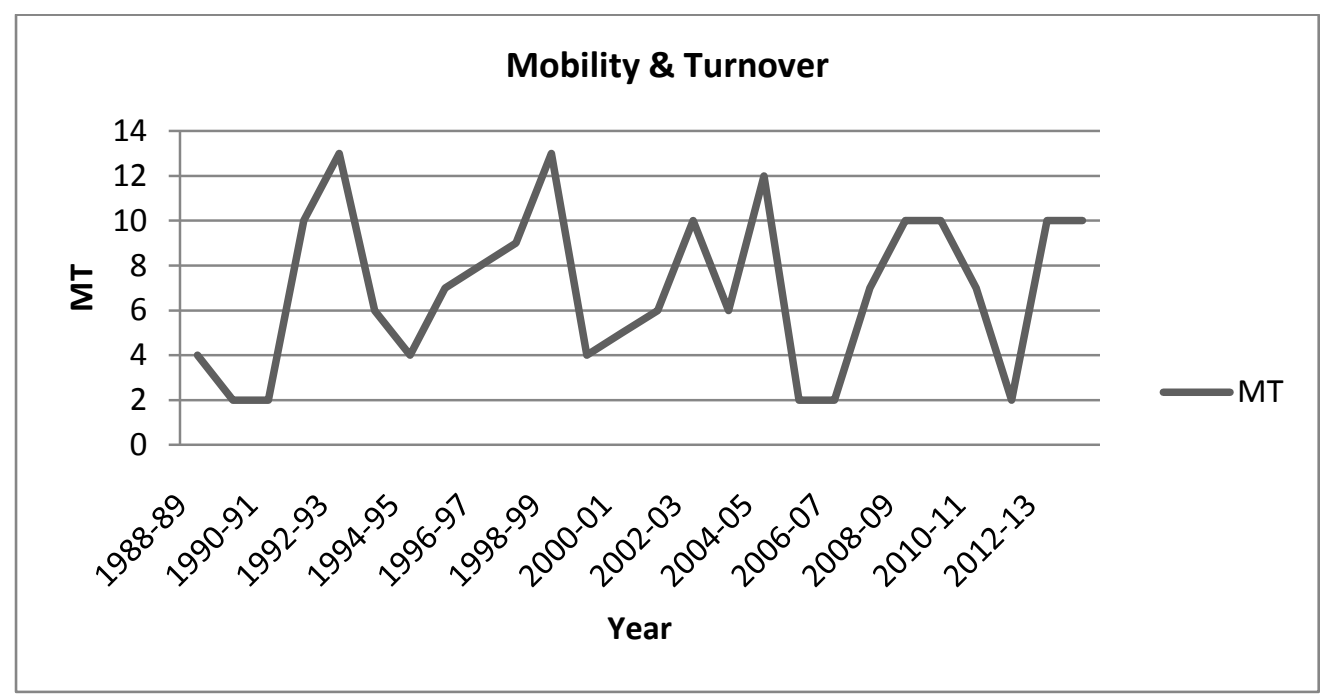

Source: Author's calculations

Figure 1: Mobility and Turnover of India's Export to World

The growth rate of mobility and turnover is positive and low but not statistically significant (Table 3). India needs to diversify its exports to provide a boost to overall export growth.

Table 3: Growth Rate of World in India's Export during 1988-89:2013-14

\begin{tabular}{|l|c|c|c|c|}
\hline & Coefficients & Standard Error & t Stat & p-value \\
\hline Intercept & -24.520 & 33.532 & -0.731 & 0.472 \\
\hline Year & 0.013 & 0.017 & 0.784 & 0.441 \\
\hline
\end{tabular}

Source: Author's calculations 
Herfindal's concentration ratio helps to judge whether India's exports have diversified or not. If concentration ratio declines, then it indicates India has diversified its export direction and vice-versa. The maximum value of Herfindal's Index is 0.104 in 1987-88 while minimum is 0.069 in 2013-14. Average value of concentration ratio is 0.086. So, world concentration ratio of India export direction is low. However, the value of concentration ratio has been continuously declining except slight increase during 1995-96 to 3003-04 (Table 4 and Figure 2).

Table 4: Herfindal's Index of Concentration in India's Export

\begin{tabular}{|c|c|}
\hline Year & HI \\
\hline $1987-88$ & $\mathbf{0 . 1 0 4}$ \\
\hline $1988-89$ & 0.101 \\
\hline $1989-90$ & 0.100 \\
\hline $1990-91$ & 0.097 \\
\hline $1991-92$ & 0.084 \\
\hline $1992-93$ & 0.088 \\
\hline $1993-94$ & 0.083 \\
\hline $1994-95$ & 0.087 \\
\hline $1996-97$ & 0.079 \\
\hline $1997-98$ & 0.087 \\
\hline $1998-99$ & 0.088 \\
\hline $1999-00$ & 0.100 \\
\hline $2000-01$ & 0.104 \\
\hline $2001-02$ & 0.100 \\
\hline $2002-03$ & 0.091 \\
\hline $2003-04$ & 0.094 \\
\hline $2004-05$ & 0.082 \\
\hline $2005-06$ & 0.080 \\
\hline $2006-07$ & 0.081 \\
\hline $2007-08$ & 0.077 \\
\hline $2009-10$ & 0.070 \\
\hline $2010-11$ & 0.075 \\
\hline $2011-12$ & 0.076 \\
\hline $2012-13$ & 0.077 \\
\hline $2013-14$ & 0.077 \\
\hline Average & 0.075 \\
\hline $5006-9069$ \\
\hline
\end{tabular}

Source: Author's calculations 


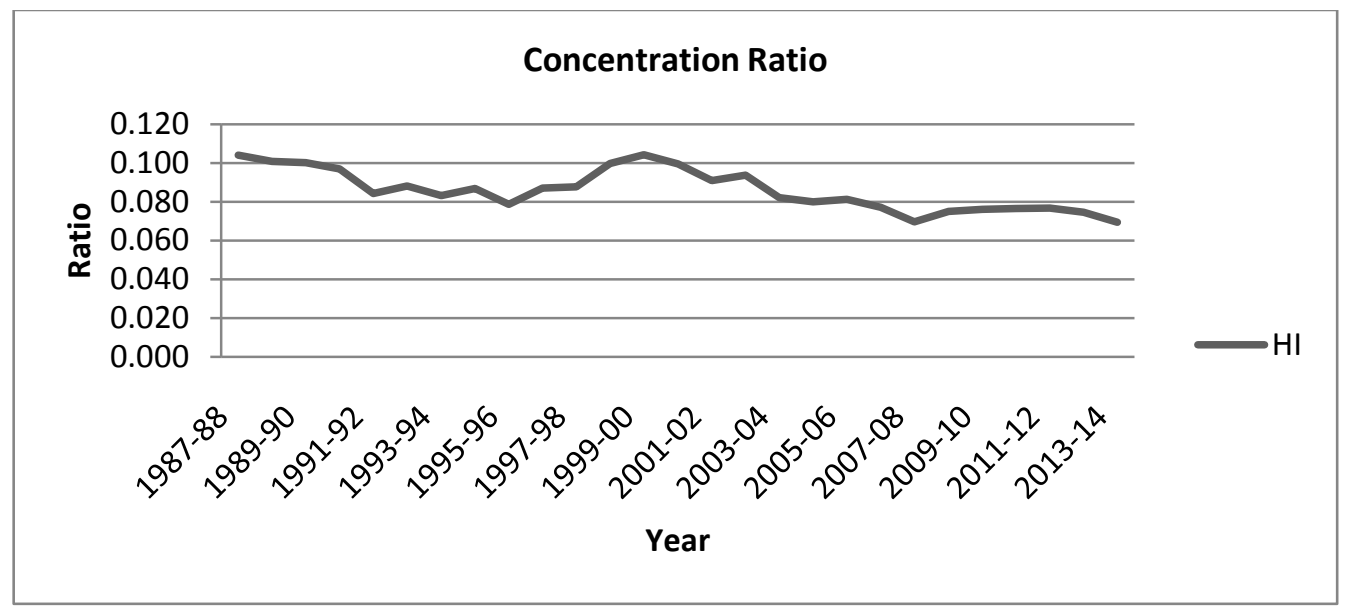

Source: Author's calculations

\section{Figure 2: World Concentration Ratio of Export from India}

The declining trends of concentration ratio of direction of export have been indicating about structural change in export pattern of India other countries in addition to traditional trading countries. This can be supplemented and complemented to the dominance pattern of direction of export. The annual compound growth rate of concentration ratio of direction is negative and statistically significant but value is low (Table 5). It means the concentration of direction of India export has been declining during last more than two decades. This indicates that new trading countries have been included for export purpose. This is also evident from dominance pattern of direction of exports.

Table 5: Growth Rate of India's Exports to the World

\begin{tabular}{|l|c|c|c|c|}
\hline & Coefficients & Standard Error & t Stat & p-value \\
\hline Intercept & 20.686 & 4.124 & 5.016 & 0.000 \\
\hline Year & -0.012 & 0.002 & -5.612 & 0.000 \\
\hline
\end{tabular}

\subsection{India exports to developed countries}

UK used to hold the first position in India's foreign trade. However, after Independence, new trade relationships were established. Now USA has emerged as the most important trading partner followed by UK, Germany and Japan. India is also making efforts to increase the exports to other countries. Within developed countries 
grouping, USA is at top position and accounted for more than one-third of India's export. The top five counties that accounted for more 90 percent of India's exports were USA, UK, Germany, Japan and Belgium. Japan is the only Asian country present in developed counties grouping and accounted for more than 13 percent. Japan is considered as a most trusted trading partner of India (Table 6).

Table 6: Rank Dominance of Developed Countries in India's Export during 1987-88 to 2013-14

\begin{tabular}{|l|c|c|c|c|}
\hline Countries & Presence & Score & IRD & RIRD \\
\hline U.S.A & 27 & 135 & 1.000 & 0.333 \\
\hline U.K. & 27 & 87 & 0.644 & 0.215 \\
\hline Germany & 27 & 73 & 0.541 & 0.180 \\
\hline Japan & 18 & 53 & 0.393 & 0.131 \\
\hline Belgium & 23 & 26 & 0.193 & 0.064 \\
\hline Netherlands & 7 & 24 & 0.178 & 0.059 \\
\hline Italy & 5 & 6 & 0.044 & 0.015 \\
\hline France & 1 & 1 & 0.007 & 0.002 \\
\hline & & Total & 3 & 1 \\
\hline
\end{tabular}

Source: Author's calculations

The dominance pattern of developed countries grouping is top-heavy and India's exports are dominated by a few developed countries during new trade regime. Then, the expected chance of mobility and turnover of India's export is low. Table 7 shows the change in ranks of India's export to developed countries in a particular year with respect to the corresponding previous year. The maximum mobility and turnover is 10 in year 2009-10 and minimum is zero in years 1989-90, 1990-91, 1991-92, 1994-95, 1999-2000, and 2002-03.

The overall mobility and turnover is 2.5 per annum on an average basis. However, the demand for Indian goods among developed countries has increased, so mobility and turnover have also increased since 2003-04. However, India needs to modify its trading strategy by entering into bilateral trade agreement with other developed countries, which may, in turn, provide a boost to India's exports. Figure 3 clearly shows that mobility and turnover is low, but the competitive pattern of India's export is somewhat increasing since 2003-04. India's export should be well diversified among developed counties. 
70 | PRAGATI: Journal of Indian Economy, Volume 3, Issue 2

Table 7: Mobility and Turnover of Developed Countries in India's Export

\begin{tabular}{|c|c|}
\hline Year & MT \\
\hline 1988-89 & 2 \\
\hline $1989-90$ & $\mathbf{0}$ \\
\hline 1990-91 & $\mathbf{0}$ \\
\hline 1991-92 & $\mathbf{0}$ \\
\hline 1992-93 & 2 \\
\hline $1993-94$ & 3 \\
\hline 1994-95 & $\mathbf{0}$ \\
\hline $1995-96$ & 2 \\
\hline 1996-97 & 2 \\
\hline $1997-98$ & 2 \\
\hline 1998-99 & 4 \\
\hline 1999-00 & $\mathbf{0}$ \\
\hline $2000-01$ & 1 \\
\hline 2001-02 & 1 \\
\hline 2002-03 & $\mathbf{0}$ \\
\hline 2003-04 & 6 \\
\hline 2004-05 & 2 \\
\hline $2005-06$ & 2 \\
\hline $2006-07$ & 2 \\
\hline 2007-08 & 8 \\
\hline 2008-09 & 4 \\
\hline $2009-10$ & 10 \\
\hline 2010-11 & 2 \\
\hline 2011-12 & 4 \\
\hline 2012-13 & 4 \\
\hline 2013-14 & 2 \\
\hline Average & 2.5 \\
\hline
\end{tabular}

Source: Author's calculations

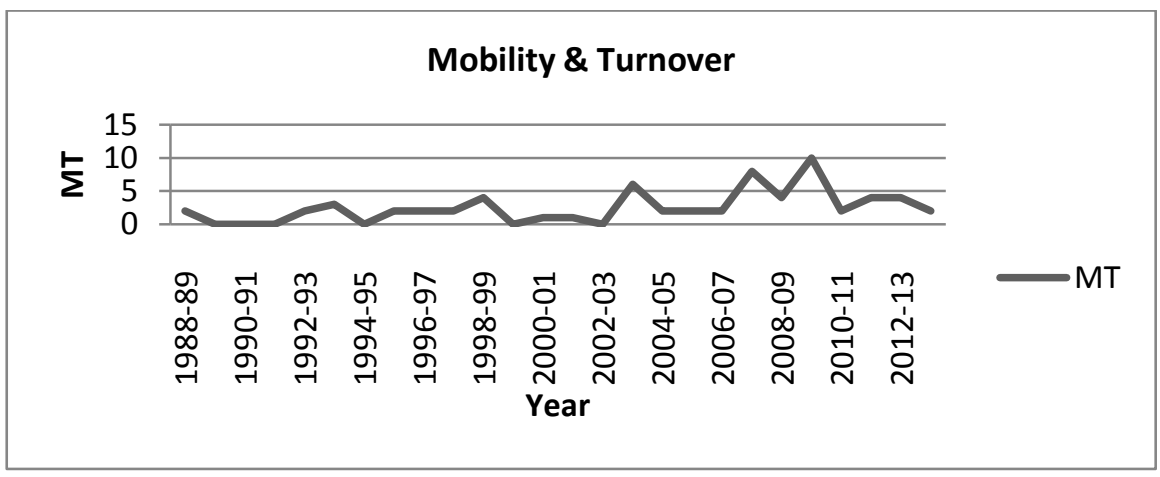

Source: Author's calculations

Figure 3: Mobility and Turnover of India's Export to Developed Countries 
Table 8 reveals that concentration ratio of India's export is moderately concentrated. This implies that India's export direction is concentrated to few developed countries. The maximum value of Herfindal's Index is 0.242 in 2002-03 while minimum is 0.160 in $1990-91$.

Table 8: Herfindal's Index of Concentration of Developed Countries in India's Exports

\begin{tabular}{|c|c|}
\hline Year & HI \\
\hline $1987-88$ & 0.182 \\
\hline $1988-89$ & 0.181 \\
\hline $1989-90$ & 0.168 \\
\hline $1990-91$ & $\mathbf{0 . 1 6 0}$ \\
\hline $1991-92$ & 0.166 \\
\hline $1992-93$ & 0.179 \\
\hline $1993-94$ & 0.179 \\
\hline $1994-95$ & 0.184 \\
\hline $1995-96$ & 0.176 \\
\hline $1996-97$ & 0.199 \\
\hline $1997-98$ & 0.195 \\
\hline $1998-99$ & 0.211 \\
\hline $1999-00$ & 0.227 \\
\hline $2000-01$ & 0.228 \\
\hline $2001-02$ & 0.226 \\
\hline $2002-03$ & $\mathbf{0 . 2 4 2}$ \\
\hline $2003-04$ & 0.227 \\
\hline $2004-05$ & 0.220 \\
\hline $2005-06$ & 0.224 \\
\hline $2006-07$ & 0.216 \\
\hline $2007-08$ & 0.191 \\
\hline $2008-09$ & 0.184 \\
\hline $2009-10$ & 0.179 \\
\hline $2010-11$ & 0.179 \\
\hline $2011-12$ & 0.199 \\
\hline $2012-13$ & 0.210 \\
\hline $2013-14$ & 0.214 \\
\hline Average & 0.198 \\
\hline
\end{tabular}

Source: Author's calculations 
72 | PRAGATI: Journal of Indian Economy, Volume 3, Issue 2

The average value of concentration ratio is 0.198 . So, the concentration ratio of India export to developed countries is moderately high. However, the concentration ratio is increasing trend except during year 2006-07 to 2010-11 (Table 8 and figure 4). The increasing trend of concentration ratio is indicating that India's exports are mainly limited to few developed countries. This can be supplemented and complemented to the dominance pattern of India's export to developed countries.

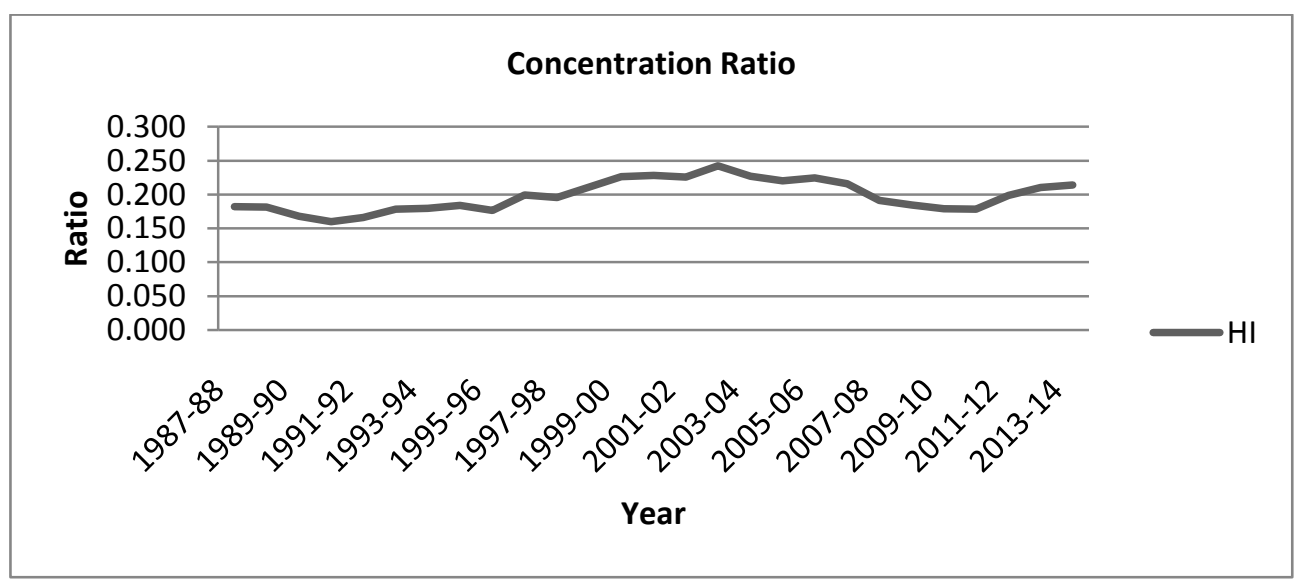

Source: Author's calculations

Figure 4: Concentration of India's Exports to Developed Countries

The growth rate of concentration ratio is positive and significant, but value is low (Table 9). Positive growth rate of concentration implies that India's export is not adequately diversified among developed counties.

Table 9: Growth Rate of Concentration Ratio of India's Export to Developed Countries

\begin{tabular}{|c|c|c|c|c|}
\hline & Coefficients & Standard Error & t Stat & p-value \\
\hline Intercept & -2.502 & 1.021 & -2.452 & 0.022 \\
\hline Year & 0.001 & 0.001 & 2.646 & 0.014 \\
\hline
\end{tabular}

Source: Author's calculations

\subsection{India export to developing countries}

India has been making consistent effort to increase its export to developing countries. UAE has emerged as the most important trading partner followed by Hong 
Kong, Singapore, Saudi Arabia and Bangladesh. Within developing countries grouping, UAE is at top position and accounted for seventeen percent of India's export. The top five counties including UAE, Hong Kong, Singapore, Saudi Arabia and Bangladesh have accounted for more than 64 percent of India's export. Bangladesh is the only SAARC country in top five developing counties grouping and has accounted for more than 9 percent. China and Russia are the only BRICS countries among developing countries and have accounted for more than 17 percent of India's export to developing countries (Table 10). India has insignificant exports to South American developing countries and African developing and under-developed countries. India needs to explore more opportunities in new developing countries for increasing its exports base. India should enter into bilateral agreement for trade with South American and African countries for increasing proportion of India's export. This will lead to an increase India shock absorption capacity and reduce dependence on developed countries.

Table 10: Rank Dominance of Developing Countries in India's Exports during 1987-88 to 2013-14

\begin{tabular}{|l|c|c|c|c|}
\hline Countries & Presence & Score & IRD & RIRD \\
\hline U.A.E. & 27 & 253 & 0.937 & 0.170 \\
\hline Hong Kong & 27 & 233 & 0.863 & 0.157 \\
\hline Singapore & 27 & 191 & 0.707 & 0.129 \\
\hline Saudi Arabia & 27 & 144 & 0.533 & 0.097 \\
\hline Bangladesh & 27 & 136 & 0.504 & 0.092 \\
\hline China & 19 & 135 & 0.500 & 0.091 \\
\hline Russia & 15 & 119 & 0.441 & 0.080 \\
\hline Sri Lanka & 24 & 64 & 0.237 & 0.043 \\
\hline South Korea & 20 & 59 & 0.219 & 0.040 \\
\hline Indonesia & 14 & 51 & 0.189 & 0.034 \\
\hline Malaysia & 20 & 45 & 0.167 & 0.030 \\
\hline Thailand & 14 & 37 & 0.137 & 0.025 \\
\hline Iran & 6 & 13 & 0.048 & 0.009 \\
\hline Kuwait & 3 & 5 & 0.019 & 0.003 \\
\hline & & Total & 5.5 & 1 \\
\hline
\end{tabular}

Source: Author's calculations

Table 11 shows the change in ranks of India's export to developing countries in a particular year with respect to the corresponding previous year. The maximum mobility and turnover is 15 in year 1996-97 and 2013-14 and minimum is 6 in year 2004-05, 
74 | PRAGATI: Journal of Indian Economy, Volume 3, Issue 2

2006-07, 2009-10 and 2011-12. The overall mobility and turnover is 9.8 per annum on an average basis. However, the demand for Indian goods among developing countries has been fluctuating, and hence mobility and turnover have also been fluctuating (Figure 5). India needs to modify its trading strategy, so that India's exports to developing countries can be increased. Growth rate is negative but not significant (Table12).

Table 11: Mobility and Turnover of Developing Countries in India's Exports

\begin{tabular}{|c|c|}
\hline Year & MT \\
\hline $1988-89$ & 9 \\
\hline $1989-90$ & 7 \\
\hline $1990-91$ & 9 \\
\hline $1991-92$ & 10 \\
\hline $1992-93$ & 12 \\
\hline $1993-94$ & 7 \\
\hline $1994-95$ & 7 \\
\hline $1995-96$ & 13 \\
\hline $1996-97$ & $\mathbf{1 5}$ \\
\hline $1997-98$ & 8 \\
\hline $1998-99$ & 12 \\
\hline $1999-00$ & 10 \\
\hline $2000-01$ & 10 \\
\hline $2001-02$ & 12 \\
\hline $2002-03$ & 12 \\
\hline $2003-04$ & 8 \\
\hline $2004-05$ & $\mathbf{6}$ \\
\hline $2005-06$ & 11 \\
\hline $2006-07$ & $\mathbf{6}$ \\
\hline $2007-08-09$ & 12 \\
\hline $2009-10$ & 11 \\
\hline $2010-11$ & $\mathbf{6}$ \\
\hline $2011-12$ & 8 \\
\hline $2012-13$ & $\mathbf{6}$ \\
\hline $2013-14$ & 12 \\
\hline Average & $\mathbf{1 5}$ \\
\hline $5019-0$ & 9.8 \\
\hline
\end{tabular}

Source: Author's calculations 


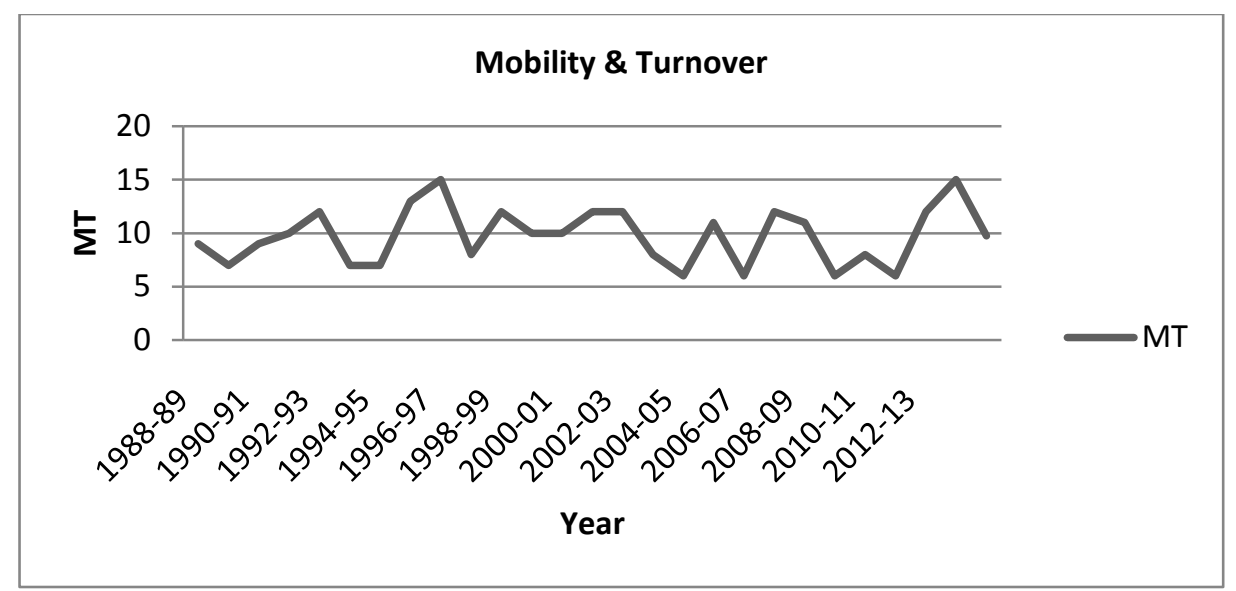

Source: Author's calculations

Figure 5: Mobility and Turnover of India's Exports to Developing Countries

Table 12: Growth Rate of Mobility \& Turnover of Developing Countries in India's Export

\begin{tabular}{|l|r|r|r|r|}
\hline & Coefficients & \multicolumn{1}{|c|}{ Standard Error } & \multicolumn{1}{c|}{ Stat } & P-value \\
\hline Intercept & 2.3710 & 15.5083 & 0.1529 & 0.8798 \\
\hline Year & -0.0001 & 0.0078 & -0.0085 & 0.9933 \\
\hline
\end{tabular}

India's exports should be well diversified among developing countries. However, Table 13 reveals that concentration of India's export is moderately concentrated during early study period. This implies that India's export direction is concentrated to few developing countries during early period of the New Trade Policy. The maximum value of Herfindal's Index is 0.247 in 1989-90 and 1990-91 while minimum is 0.085 in 1996-97. Average value of concentration ratio is 0.123 . So, the concentration ratio of India's exports to developing countries is low since 1992-93. However, the concentration ratio is declining trend except during year 2008-09 to 201112 (Table 13 and Figure 6). The declining trend of concentration ratio implies India's export is diversifying among developing countries. This can be supplemented and complemented to the dominance pattern of India's export to developing countries. The growth rate of concentration ratio is negative and significant, but value is low (Table 14). Negative growth rate of concentration implies India's export has been diversified among developing counties but it need to be more diversified among developing countries. 
76 | PRAGATI: Journal of Indian Economy, Volume 3, Issue 2

Table 13: Herfindal's Index of Concentration of Developing Countries in India Exports

\begin{tabular}{|c|c|}
\hline Year & HI \\
\hline $1987-88$ & 0.215 \\
\hline 1988-89 & 0.204 \\
\hline $1989-90$ & 0.247 \\
\hline $1990-91$ & 0.247 \\
\hline $1991-92$ & 0.134 \\
\hline $1992-93$ & 0.089 \\
\hline 1993-94 & 0.095 \\
\hline $1994-95$ & 0.096 \\
\hline $1995-96$ & 0.090 \\
\hline 1996-97 & 0.085 \\
\hline $1997-98$ & 0.090 \\
\hline $1998-99$ & 0.103 \\
\hline 1999-00 & 0.108 \\
\hline $2000-01$ & 0.100 \\
\hline 2001-02 & 0.088 \\
\hline 2002-03 & 0.088 \\
\hline 2003-04 & 0.096 \\
\hline 2004-05 & 0.107 \\
\hline 2005-06 & 0.106 \\
\hline 2006-07 & 0.108 \\
\hline $2007-08$ & 0.104 \\
\hline 2008-09 & 0.127 \\
\hline $2009-10$ & 0.132 \\
\hline $2010-11$ & 0.133 \\
\hline 2011-12 & 0.125 \\
\hline $2012-13$ & 0.114 \\
\hline 2013-14 & 0.097 \\
\hline Average & 0.123 \\
\hline
\end{tabular}

Source: Author's calculations

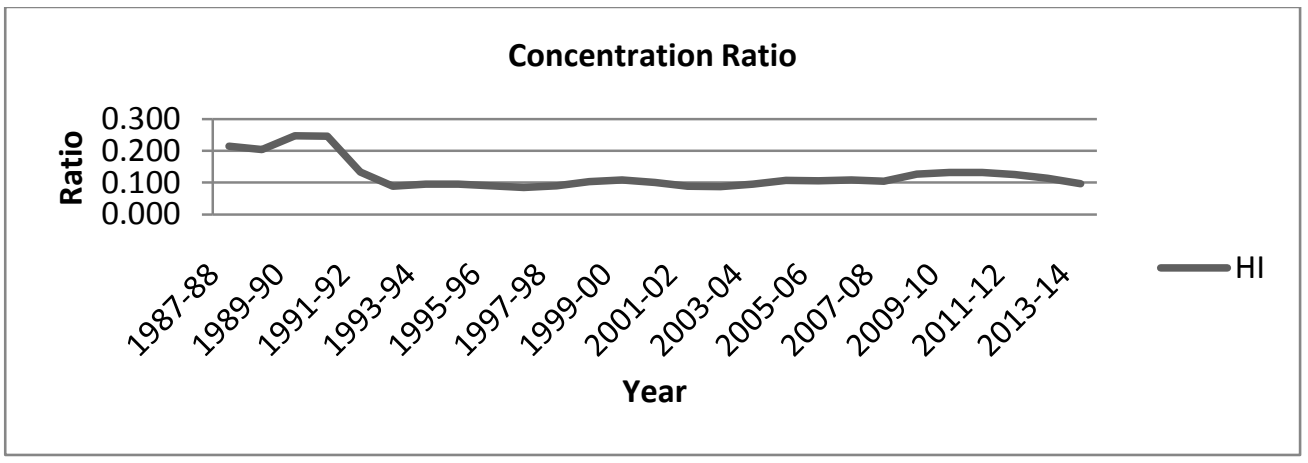

Source: Author's calculations

Figure 6: Concentration of India's Export to Developing Countries 
Table 14: Growth Rate of Concentration Ratio of India's Exports to Developing Countries

\begin{tabular}{|l|c|c|c|c|}
\hline & Coefficients & Standard Error & t Stat & p-value \\
\hline Intercept & 29.142 & 14.580 & 1.999 & 0.057 \\
\hline Year & -0.016 & 0.007 & -2.146 & 0.042 \\
\hline
\end{tabular}

Source: Author's calculations

\subsection{Concluding Remarks}

There has been a marked change in the perception of the government of India and its policymakers in the past two decades towards the role of trade in the strategy of development of the country. The basic thrust of this regime has been on globalisation of the Indian economy, improving its competitiveness and expansion of exports to ease pressure on balance of payments. In case of world level, India's exports have been diversified during the last more than two decades. USA has emerged as top trading partner of India. The top five countries as export destinations have accounted for more than 62 percent exports from India. UAE and Hong Kong are the Asian countries in top five. The growth rate of mobility and turnover is positive and low but not statistically significant. World concentration ratio of India's export is declining and low. The declining trend of concentration ratio of direction of exports indicates that the destination of exports is moving towards developing countries. In case of developed countries, USA is at top position and accounted for more than one-third of India's exports. The overall mobility and turnover is low. Concentration ratio of India's exports to developed countries is moderately high. The increasing trend of concentration ratio is indicating that India's exports are mainly limited to few developed countries. However, recent trends show that the share of developing countries has increased. In case of developing countries, UAE has emerged as the most important trading partner followed by Hong Kong, Singapore, Saudi Arabia and Bangladesh and accounted for more than 64 percent of India's export to developing countries. Bangladesh is the only SAARC country in top five developing countries, while China and Russia of BRICS countries are in top list of India's exports. Mobility and turnover are fluctuating. Growth rate of mobility and turnover is negative but not significant. Concentration ratio trend is declining.

India's direction of foreign trade has exhibited a structural shift during the last two decades. Trade volume and trade share of emerging and developing economies has increased while the share of conventional trading partners (developed countries) has shown a declining trend. 


\subsection{Policy Implications}

Keeping in mind the trends that have been analysed with regard to India's exports, the following strategies may be adopted to give a boost to India's export:

- India's export is concentrated in a few countries. India should diversify its export globally under the framework of World Trade Organization (WTO). Diversification of India's exports would lead to an increase in the absorption capacity of India in case of international shock and recession such as global financial crisis in 2008.

- Indian goods have limited presence in South American and African countries. India can enter into these new markets and countries for exports from India.

- India has significantly increased its export volume to Arab countries. However, volume of India's export is not significant in case of SAARC countries and BRICS counties. Thus, India should plan strategies to increase exports to SAARC to benefit from regional economic integration. It should also take advantage of closer cooperation among BRICS countries and expand its export base within these countries.

\section{References}

Bhat, T.P. (2011). Structural changes in India's foreign trade. Working Paper, Institute for Studies in Industrial Development, New Delhi.

Bodenhorn, H. (1990). Entry, rivalry and free banking. Review of Economics and Statistics, 72(4): 68286.

Malik, J.K. (2005), India's exports- Policy defeating exchange rate arithmetic. Economic and Political Weekly, Dec 24-31: 5486 - 5496.

Mathor, Amol Dattatraya \& Sagar, Sunanda. (2015). India's international trade since globalization. The Business and Management Review, 5(4), 89-94.

Mishra, Devi Prasad, Jena, Artta Bandhu \& Shil, Nikhil Chandra (2011). India's foreign trade during liberalization era: An assessment. Journal of International Economic Review, 4(1): 39-50.

Murthy, K.V.B. (2011). State of Environment in South Asia. In R. Jha (Ed.), Handbook of South Asian Economics, (pp. 289-08). London: Routledge. 
Murthy, K.V.B. \& Deb, A.T. (2008). Operational zing and Measuring Competition: Determinants of Competition in Private Banking Industry in India. Paper presented in annual money and finance Conference, IGIDR, Mumbai, 18-19 January.

PHD Chamber. (2014). Structural Changes in India's Direction of Foreign Trade. PHD Research Bureau PHD Chamber Of Commerce and Industry, New Delhi.

Taneja, R. (2013). India's export performance analysis - An analysis. Global Journal of Commerce \& Management Perspective, 2(5): 63-67.

Veeramani, C. (2007). Sources of India's exports growth in pre and post-reform periods. Economic and Political Weekly, July 23-30: 2419 - 2427.

Virmani, A., (2003). India's External Reforms- Modest Globalisation, Significant Gains. Economic and Political Weekly, 38(32): 3373 - 3390. 